\section{International Scientific Journal Theoretical \& Applied Science}

Munira Mahamadjanovna Kaharova

Senior researcher

"National idea and social philosophy" Dept.

The Mirzo Ulugbek National University of Uzbekistan

Tashkent, Uzbekistan naumenko06@mail.ru

Year: $2016 \quad$ Issue: 1 Volume: 33

Published: $30.01 .2016 \quad \underline{\text { http://T-Science.org }}$

SECTION 30. Philosophy.

\title{
PHILOSOPHICAL-LEGAL FOUNDATIONS OF THE IDEAS OF PLURALISM AND THE MULTIPARTY SYSTEM (ON THE EXAMPLE OF UZBEKISTAN)
}

Abstract: In this article some interested philosophical-legal points of view on the ideas of pluralism and the multiparty system in Uzbekistan are consider. Philosophy of law pays a big attention to these questions.

Key words: philosophy of law, the Republic of Uzbekistan, the Constitution, law, pluralism, multiparty system. Language: English

Citation: Kaharova MM (2016) PHILOSOPHICAL-LEGAL FOUNDATIONS OF THE IDEAS OF PLURALISM AND THE MULTIPARTY SYSTEM (ON THE EXAMPLE OF UZBEKISTAN). ISJ Theoretical \& Applied Science, 01 (33): 35-43.

Soi: http://s-o-i.org/1.1/TAS-01-33-8 Doi: crossef http://dx.doi.org/10.15863/TAS.2016.01.33.8

In the modern world, experiencing a fundamentally important and new stage in its development, searching for new approaches of formation and development of political systems, the modernization and democratization of state and social structure. There is an intense search to find their own model of promoting democracy, civil society and progress, the possible ways to achieve it taking into account the peculiar characteristics of each people and society.

Uzbekistan has refused the imposed shocks, deceptive ideas about self-regulation of the market economy and chose the evolutionary approach in the transition from administrative-command towards market system of management, the path of gradual and phased reforms, acting upon known principles of "not having built a new house, don't destroy the old one" and "reforms not for reforms, but for the people".

On the basis of the fundamental provisions and requirements of the Constitution of the Republic of Uzbekistan was adopted its own model of fundamental reform and modernization of the country, five basic principles which underlie the current intense democratic, socio-political and economic development of the country, loyalty and wisdom which is fully confirmed by experience. They are the priority of economics over politics; the state in transition plays the role of the main reformer; the superiority of law; the implementation of strong social policy and the evolutionary in reforms.
Today it is possible to assert with confidence that the model enabled the evolutionary, without revolutionary and social upheaval to create the national statehood, to strengthen state sovereignty, to ensure sustainable and dynamic development of the political system, civil society, the national economy, to carry out deep democratic political, economic and social reforms. This shows the correctness of the chosen in the first years of independence own path of development and progress and underlying evolutionary and gradual modernization of society.

In the course of building a democratic legal state with a developed market economy, the formation of a strong civil society, the emphasis was on system development of a multiparty system, creation of conditions for the formation of an independent, stable, active, supported by wide sectors of the population political parties and other public associations. The analysis of the activity of political parties in Uzbekistan allows allocating following stages and features of their formation and development.

The first stage (1991-2000). On this stage of priority reforms and transitions and building the foundation of national statehood was solved the problem of the departure from the monopoly of ideology and policy one of the existing political parties. There have been created the necessary legislative and political conditions for the establishment of a multiparty system in the country. 
At this stage also addressed the following key task of modernising the country in the sphere of formation of a multiparty system.

First, a legislative conditions for the transition from monoparty socio-political system into a real multiparty system, from ideological fundamentalism - political pluralism.

The turning point in the creation of legislative, legal base for the formation in Uzbekistan of political pluralism and the multiparty system that meets international standards of parliamentary democracy was the adoption in 1992 of the Constitution of the Republic of Uzbekistan [1]. The Constitution enshrines a number of important initial concepts and principles, the place of political parties in the state power system. Especially: - the right of citizens to form political parties and other public associations, to participate in mass movements (Article 34), as well as the classification of political parties according to their legal form, public associations (Article 56); - protection of rights, freedoms and dignity of persons constituting an opposition minority in political parties, public associations, mass movements and in representative bodies (Article 34). This stipulates that no section of society, political party, public Association, movement or individual may speak on behalf of the people of Uzbekistan (article 10). Established the state's obligation to enforce the rights and lawful interests of public associations, creation of equal legal opportunities for participation in public life and the prohibition of intervention of state bodies in the activity of public associations (article 58); - the ban on creation and activity of political parties and other public associations, aimed at forcible change of the constitutional system, undermining state sovereignty, integrity and security of the Republic, constitutional rights and freedoms of citizens, propagandizing war, social, national, racial and religious enmity, encroaching on the health and morality of the nation, as well as paramilitary organizations and political parties based on ethnic and religious grounds, secret societies and associations (article 57); - define political parties as organizations that Express political will of various social strata and groups and through their democratically elected representatives shall participate in the formation of state authority (article 60).

Thus, the Constitution in 1992 created a solid legal basis for the formation of a new political system of society on a multiparty basis, decide the most important tasks of the transition period - the development and strengthening of democratic institutions such as branched multi-party system and other social organizations, designed to represent interests of various strata of the population. The role of the state in the formation of civil society was to eliminate any obstacles and barriers that impede the emergence, formation and development of political parties and social movements, which provide for a representative democracy.

The Law "On political parties" enacted in 1996 [2] has established the necessary legal framework for the effective functioning of multi-party system, securing the provision that none of the existing parties can claim the sole right to determine the policy of the state. The adoption of the law legally enshrines growing diversity and a broad range of new political standing of the society, allowed to gradually develop the structure of social organizations designed to maintain a balance of interests in the country.

There was established the principle of voluntary association of citizens in political parties on the basis of their common views, interests and goals. Political parties were guaranteed the right to propagate their ideas, goals and objectives, participate in training relevant government decisions, elections of bodies of state power, to establish their own mass media, to form their factions in the legislative body, organized to achieve its program goals and objectives.

Secondly, provided legal guarantees for the transition from an electoral system based on the "leading role" of the party direct political action, to a multi-party electoral system that meets widely accepted standards. There was created the necessary legal framework to ensure the most important principle of democracy - the right of choice, free will of the people, participation of citizens in managing the affairs of the state and society.

The first Law "On elections to the Oliy Majlis of the Republic of Uzbekistan" [3], adopted on 28 December 1993, already possible at that stage of reforms consistent with the widely accepted standards of organizing and holding multiparty elections. With the adoption in 1994 of the laws "On guarantees of electoral rights of citizens" [4], "On elections to regional, district and city Kengashes of people's deputies" [5] and other acts of legislation, the country has developed, consistent with democratic requirements of the electoral system.

There have been established organizational and legal, material and technical conditions for free, active participation of citizens, political parties in the electoral processes, reliable guarantees of full realization of their voting rights.

All this has become the lynchpin of the entire work on the formation of a fundamentally new state arrangement, provision of the democratic separation of powers, the formation and development of genuine multi-party system.

For the first time in the history of Uzbekistan on the basis of a new electoral law in December 1994 were held open democratic elections to a new Parliament - the Oliy Majlis, also formed a new constitutional-legal framework in terms of separation of powers and multi-party system. 
Elections were held with the active participation of citizens in each electoral district ran two or three candidates and the voters were given the right of a real choice. High about democracy and organization of the electoral process in this period and indicates that the 250 parliamentary seats were contested 634 candidates from two political parties - people's democratic party and party "Vatan Taraqqiyoti", and from local representative bodies [6].

Furthermore, elections have completed an important stage in the establishment of a new system of state power. Was implemented the constitutional principle of separation of powers, strengthened the Executive and judicial branches of government.

According to the results of the 1994 elections, the most significant place in the Oliy Majlis took the people's democratic party received 69 seats, then the party "Adolat" - 47 seats and "Vatan Taraqqiyoti" 14 seats, i.e. political parties together had a majority of seats in the Parliament [7].

Overall, during this period the country has developed the foundations of a new democratic political system, ensuring wide participation of citizens in managing the affairs of the state and society. There has been dynamic growth of the political and social consciousness of citizens, the rise of their political activism that, in turn, contributed to increasing the role and importance of parties in state and public life.

These changes have created a fundamentally new legal framework for the upcoming parliamentary elections in 1999, during which parliamentary seats in the Oliy Majlis of the second convocation has fought five political parties, initiative groups of citizens and candidates from local representative bodies of state power. The elections themselves were characterized by a higher level of competition of candidates (in some districts their number has reached 7 people) and the increased demands on them by voters.

In the activity of the Oliy Majlis of the second convocation were registered and became operational fractions of all political parties represented in Parliament, has been the development of factional activity. The number of political parties represented in the Parliament were: the National democratic party "Fidokorlar" - 53 seats (in April 2000 in view of commonality of political goals and interests have merged with the NDP "Fidokorlar" and "Vatan Taraqqiyoti", which, in turn, subsequently, in 2008, merged with the party "Milly Tiklanish"), PDPU 49, the Social democratic party "Adolat" - 11 and Democratic party "Milly Tiklanish" - 10.

Thus, the 1999 elections, becoming a significant step forward in democratic reformation of the country, simultaneously revealed the need not only for further improvement of normative-legal regulation of the electoral processes, but also in qualitatively new approaches to the organization of representative government.

Third, it initiated the formation corresponding to modern requirements of democratic parliamentary system, adopted comprehensive measures to enhance the role of the legislature in the structure of political institutions, the consistent expansion of the functions and powers of Parliament as creating the necessary socio-political conditions, more political, legal consciousness and legal culture of the population.

The Parliament in cooperation with the other branches of government became the guarantor of the preservation of political stability, peace and tranquility, was located in the center of all renewal processes in the socio-political, spiritual and cultural life of the country, creation of legislative base of reforms and consistent implementation of these tasks.

The Oliy Majlis has achieved tangible results in the sphere of forming the legal basis of civil society, institutional framework for the protection of human rights. In order to ensure parliamentary control over the effective implementation of existing legislation on human rights in the Republic of Uzbekistan state bodies, local authorities, enterprises, institutions, public associations and officials, in 1995, Parliament created the Ombudsman of the Oliy Majlis for human rights (Ombudsman).

Thus, conditions were created for transition to a subsequent stage of reform, and the logical result of the first stage was the preparation and holding of elections to the Oliy Majlis of the second convocation (1999).

The second stage (2000-2010). The period of active democratic renewal and modernization of the country is characterized by the accumulation of parties political experience and political maturity, ensure their financial autonomy, determining their own place in society and their permanent electorate.

The main tasks in the area of further development and strengthening of multi-party system that were solved at this stage of the reforms was limited to the following: creation of necessary conditions for improving political, the economic activity of citizens and the realization of man; further strengthening and promotion of the rights and freedoms, democratic values in the minds of people; improving the system of state and public institutions aimed at protecting the rights and freedoms of citizens; ensuring pluralism of opinions and freedom of expression.

At that time it was necessary to ensure that the multi-party system actually came into the life of society and to lay the foundations of a competition of views and ideas, to create a new political field of rivalry between the parties.

It is particularly noteworthy that on the eve of independence, the foundations of a new market economy, mechanism of market economic relations with the creation of institutes of market infrastructure 
and a competitive environment, revitalization and priority development of private property, has had a significant impact on the structure of society as a whole. Due to the privatization and full privatization of key sectors of the economy, trade, the service sector in the country actually formed a mixed economy, in which increasingly large role played by small business and private entrepreneurship, private farms and dekhkan farms. The share of small business and private entrepreneurship in GDP has increased from $1.5 \%$ in the early 1990 -ies to $31 \%$ in 2000 and $38.2 \%-2005[8]$.

In the end, the country appeared and began to grow a new class of owners-entrepreneurs, which from year to year began to play an increasingly important role in the life of the country. It is the middle class of owners has become a mainstay form of civil society began to play a crucial role in state and public construction, maintaining and strengthening socio-political stability, the formation of an economically sustainable and stable society. As a result, in the political field of the country arose a new Movement of entrepreneurs and businessmen Liberal Democratic Party of Uzbekistan (UzLiDeP), which represents and protects the interests of the middle class of owners, entrepreneurs and farmers, etc.

Positive impetus to the increase of political activity of parties stressed the adoption of the law "On financing of political parties" [9], which created the possibility of legal regulation of financing of political parties. The sources of their funding were also assigned entrance and membership fees, profits received from entrepreneurial activity, the state budget and donations of legal entities and citizens of the Republic.

While the inclusion of financing parties from the state budget has provided an important stimulus for the activity of political parties, increasing demands from voters to parties and candidates they voted for a more efficient implementation of those social programs that meet the vital interests of the voters.

Since 2005, the government began the funding of political parties for the exercise of their statutory activity. The basic principles of funding political parties in this case determined the legality and transparency. The amount of subsidies allocated to a particular party is determined by the presence of the faction, and obtained seats in the Legislative chamber.

This has led to a significant intensification of the statutory activities of parties in local organizations. Started to develop the necessary organizational prerequisites for the strengthening of their work among the electorate and expand the activities of party groups in the deputy corps of the local Kengashes of people's deputies.
Parliamentary reform also entailed corresponding changes in the electoral system, which allowed to strengthen the participation of political parties in elections to representative bodies of power. In particular: - it was determined that candidates will be nominated from representatives from political parties and initiative groups of citizens (the excluded provisions for the nomination of candidates for deputies of local representative bodies of state authority); - improved a number of other rules governing the participation in elections of political parties. In particular, it was stipulated that women should constitute at least 30 percent of candidates nominated from political parties.

For the parliamentary elections of 2004 was improved election system that meets international standards. On 26 December 2004 General elections ensured the practical implementation of parliamentary reforms, has demonstrated the efficiency of the reformed electoral system, ensuring full representation in the newly elected Legislative chamber of all 5 existing in the country political parties. Participated in the last elections political parties already had a prominent political personality.

During elections, the UzLiDeP of the 120 seats in the Legislative chamber received 41, the People's Democratic Party (PDPU) - 28, the NDP "Fidokorlar" - 18, DP "Milliy Tiklanish" - 11, SDP "Adolat" - 10. This allowed all parties to form in the lower house of their own faction.

After the elections in the Jokargy Kenes of Karakalpakstan, regional and Tashkent city Kengashes of people's deputies were elected 823 deputies, including - 331 from UzLiDeP (40,2 \%), 301 from the PDP Uzbekistan $(36.6 \%)$ and 88 from NDP "Fidokorlar" (10,7\%), 40 from the SDP "Adolat" (4,9\%), 30 from " Milliy Tiklanish " $(3,6 \%)$.

As a result of the 2004 elections in the lower house of Parliament, in the person of the faction UzLiDeP, received a relative majority of parliamentary seats, emerged the so-called "party of power". This was the incentive to, in order to more effectively promote bills related to the implementation of its programme priorities with the faction UzLiDeP joined the faction of NDP "Fidokorlar" and SDP "Adolat", creating a Democratic bloc, which amounted to a parliamentary majority. At the same time the people's democratic party of Uzbekistan declared itself in opposition to the parliamentary majority.

Thus, for the first time in the history of the country in the lower house of the Oliy Majlis were institutionalized parliamentary majority and opposition parliamentary minority, explicitly delineated the formation in Uzbekistan is typical for modern democratic parliamentarism branches of parliamentary balance of political interests. This marked the beginning of the formation in Parliament 
of a modern mechanism of competition and healthy competition, and also created conditions for further development of constructive rivalry between political parties in tackling critical socio-political challenges facing the society.

The key and critical importance in deepening democratic reforms was played by the adoption of the Constitutional Law "On strengthening the role of political parties in renewal and further democratization of state governance and modernization of the country". Today political parties have become the most important tool for increasing political and public activity of citizens, the expression of the will and opinions of the population, primarily during the implementation of the electoral processes, the formation of bodies of state power in the centre and in the field. Taken legal measures to the legislative definition of the status of the parliamentary majority and parliamentary opposition, to the election of the leaders of the parliamentary fractions Deputy Speaker of the Legislative chamber.

Adopted legal mechanisms have radically changed the role and place of political parties in organization of activity of the Parliament, as well as in the formation of bodies of representative and Executive bodies, exercising control over their activities.

The introduction, in particular, the mandatory procedure for holding consultations with the factions of political parties on the candidature for the post of Prime-Minister, is strictly regulated and the mechanism of its adoption by the Parliament is an important step towards deepening of democratic reforms in the sphere of state construction.

Crucial have provided by Constitutional Law the rights of the political party factions in the Legislative chamber to take the initiative about resignation of the Prime-Minister and party groups in local Kengashes - the initiative about resignation of the Governor of the region, which in itself is concrete evidence of the increased role of political parties in the country.

Election of 2009 was held subject to the provisions of the Law of the Republic of Uzbekistan from 2008 "On amendments and additions to some legislative acts of Uzbekistan in connection with improvement of legislation on elections" [11] and became an important stage in deepening the reforms on democratic renewal and modernization of the country.

In the electoral system of the country were made due to time requirements and international standards changes and additions aimed first of all at further liberalization and democratization of the election legislation. In particular, the growing role and influence of political parties, increasing the number of their authorized representatives participating in the election process, granting them additional rights and powers and, in General, the empowerment of voters allowed to improve the electoral system that has received broad support from the international community.

As a result of the changes made to the electoral law, the results of the upcoming elections has been greatly expanded representation of citizens in the Legislative chamber of the Oliy Majlis of the Republic of Uzbekistan, where the number of seats increased from 120 to 150 . This introduced a new principle aimed at the protection of the environment, rational use of natural resources and ensuring ecological safety of the population, according to which the Parliament is allocated 15 places for the deputies from the Ecological movement of Uzbekistan.

The legislation made other changes to improve the electoral system, which ensured compliance with the principles of a multiparty system, alternative, transparency, freedom and fairness of the electoral process.

Many local and foreign experts, who observed the elections in Uzbekistan in 2009, drew attention to the fact, as was the election campaign in conditions of inter-party discussion, battle of ideas and programmes proposed by political parties. More than 500 candidates represented four parties.

According to the results of the elections to the lower house of Parliament were elected from UzLiDeP - 53 seats $(39.3 \%)$, from the PDP Uzbekistan - 32 seats $(23,7 \%)$, from the DP "Milly Tiklanish" - 31 seats $(23 \%)$ and from the SDP "Adolat" - 19 seats (14\%). Thus, all 4 operating parties won sufficient number of seats and formed their parliamentary factions. There also has formed a group of deputies elected from the Ecological movement of Uzbekistan. The leaders of all party factions and parliamentary group were elected ViceSpeaker of the Legislative chamber.

As a result of the practical implementation of the provisions of the constitutional law "On strengthening the role of political parties in renewal and further democratization of state governance and modernization of the country" and changes to the electoral law, the results of the 2009 elections there has been a significant strengthening of party representation in elected bodies of state power, which contributed to a noticeable revitalization of the associations of parliamentary parties at all levels.

The third stage $(2010$ - present time). The President of the Republic of Uzbekistan Islam Abduganievich Karimov at the joint session of Legislative chamber and Senate of the Oliy Majlis of Uzbekistan on 12 November 2010 the Concept of further deepening democratic reforms and formation of civil society in the country marked the beginning of a new phase of democratic renewal of society and modernization of the country. As stressed by the head of state, adopted the Concept "... is a long term Program of the interrelated political and 
economic reforms, democratization and liberalization of state power and governance, ensuring independence and autonomy of the judiciary, freedom of expression and information, freedom of choice and development of electoral system, formation of civil society in conditions of globalization and rapidly changing modern world".

For these purposes, on April 18, 2011 adopted the law "On amendments and additions in separate articles of the Constitution of the Republic of Uzbekistan (articles 78, 80, 93, 96 and 98)". In accordance with this act introduced a number of significant changes and additions to the Constitution aimed at: the creation of a system of government and governance based on a fundamentally new that meets the highest democratic principles, the legal mechanism of distribution of powers between President, legislative and Executive branches; the extension of authority and control functions of the Parliament over the activities of Executive bodies; strengthening the role of political parties in implementing parliamentary control over the activities of the government.

In accordance with this law, first, equipped with the fundamentally new constitutional procedure of appointment of Prime-Minister of the Republic of Uzbekistan. With the consolidation in the new wording of article 98 of the Constitution, the constitutional order, under which the candidate for Prime Minister nominated by the political party victorious in parliamentary elections, or more parties who have obtained an equal number of seats, is fundamentally changing the system of formation and functioning of the Executive branch. A decisive role here include such things as political parties, the most important institution of civil society, implements the constitutional mechanisms of direct democracy foreseen in the Constitution.

Secondly, for the first time in parliamentary practice was established by the Institute of vote of no confidence in the Prime Minister - the Prime Minister of the country, which in the case of the persistent contradictions between the Prime Minister and the Legislative chamber if they receive at least two thirds of votes of the total number accordingly of deputies of the Legislative chamber and Senate of the Oliy Majlis, the Parliament can issue a vote of no confidence to the Prime Minister. In this case the President takes the decision to release the Prime Minister from office. The adoption of a vote of no confidence leads to the resignation of the entire government.

This Institute entered in to reinforce the powers of Parliament to oversee the implementation of laws by bodies of Executive power and is intended to enhance the role of the legislature in the political system of the country and the government's responsibility for ensuring continuous and quality execution of adopted laws.
Thirdly, the right of the President of the Republic of Uzbekistan take decisions on matters within the competence of the Cabinet of Ministers of the Republic of Uzbekistan.

Fourthly, important of fundamental importance in deepening democratic reforms and other amendments to the Constitution. In particular, set the order in which the decrees of the President of the Republic of Uzbekistan on the appointment and dismissal of the Chairman of the accounting chamber shall be approved by the Senate, eliminates the provision in accordance with which the President can make decisions on issues referred to the competence of the Cabinet of Ministers.

These innovations in the Basic law significantly expand the possibilities of parliamentary control over the activities of agencies of the Executive branch, greatly enhance the role and place of Parliament in the system of bodies of state power, expand the powers and control functions of the legislative branch, increase the requirements on the quality of legislative and control-analytical work of the Supreme representative body of the country.

A serial implementation also creates conditions for a radical enhancement of the role of political parties in formation of bodies of Executive power, implementation of parliamentary control over their activities, considerable strengthening of political, inter-party competition — the most important component of a democratic society.

In accordance with the fundamental innovations in the Basic law was adopted several important legislative acts aimed at improving the activities of the Parliament, strengthening the role and influence of political parties in the implementation of socioeconomic, socio-political reforms, upgrading and modernization of the country.

Essential in the solution of these problems is the adoption of the law "On introducing amendments and addenda to the Law of the Republic of Uzbekistan "On Regulations of the Legislative chamber of the Oliy Majlis of the Republic of Uzbekistan" [14] in April 2013. Its adoption was due to modern realities and the logic implemented in the country democratic reforms and transformations, which require further development and strengthening of the institutions of representative democracy, in particular the activities of the Parliament when taking into consideration, the preparation for the final discussion and adoption of laws and strengthening the role of parliamentary associations on these stages of the legislative process.

In accordance with the law the following changes and additions to the Regulations of the Legislative chamber:

First, the law includes a provision (Article 81), providing for the establishment of the Kengash of the Legislative chamber of the Coordination group on organization of consideration of introduced draft 
laws and drafts of other normative-legal acts of the employees of the staff of the Legislative chamber, designed to carry out registration (accounting) of submitted projects and to accompany them in all stages of review.

Secondly embodied a more democratic, open mechanism for the distribution of the received projects (Article 13), whereby the Kengash of the Legislative chamber at its meeting collectively defined by the Committee responsible for the preliminary consideration of the bill.

Thirdly, in order to provide the factions of political parties more effectively implement their responsibilities in law-making activity of the Legislative chamber establishes the procedure, according to which, along with the responsible Committee, the draft law in the same terms sent in the faction (Deputy groups). Factions are granted the right to proceed to the consideration of draft laws and other normative legal acts simultaneously with the responsible Committee. Without opinions and proposals of fractions (Deputy groups) on the bill, the Committee responsible has no right to impose an opinion.

This provision expands the rights of factions (parliamentary groups) for participation in the work on the draft law at all stages of the legislative process and allows them already at the stage of preliminary consideration of the bill to form its position based on the program goals of political parties, interests of the electorate, to defend their opinion on different provisions of the bill.

In general, the law will significantly improve the legislative process in the lower house of the Parliament by expanding the rights and powers of the factions of political parties in legislative activity, increased their role and responsibility in making laws.

In addition, it assures political parties of new, more effective mechanisms to Express their programming tasks, the protection of the interests of the electorate. It promotes the participation of political parties through the activities of their fractions in the legislative process, increasing their opportunities to influence decisions made by the chamber of decision at all stages of consideration of the bill, to articulate and defend their positions on the bill, based on program documents of their political parties and voters. Moreover, to strengthen the role and responsibility of political party factions in improving the quality of laws, from the point of view of mainstreaming in the standards of laws for the interests of all segments of the population.

The main meaning in the further liberalization of the political system, the development of a multiparty system and strengthening of inter-party competition has adopted the Law "On amendments and additions to some legislative acts of the Republic of Uzbekistan" [15], including the Law "On political parties".

This act, firstly, the law more clearly defined the conditions and procedure of education of party groups, in particular, set a lower limit on the number of deputies required for their education in the Jokargy Kenes of Karakalpakstan, Kengashes of people's deputies of oblasts, Tashkent city and cities (regional centers) - at least five deputies.

Secondly, it is stipulated that the activities of the party groups shall be terminated in the following cases: own initiative of the party groups; the expiration of the term of office of the Jokargy Kenes of the Republic of Karakalpakstan or the Council of people's deputies; reduce the number of MPs included in the party groups, below the limit required for its formation; termination of activities of the concerned political party.

Thirdly, along with established by the applicable laws of power, the party groups are entitled to make proposals: - for candidates as chairmen and Vice-chairmen and members of committees or commissions of the relevant representative body; - on the hearing at the sessions of the Jokargy Kenes of the Republic of Karakalpakstan, the Council of people's deputies of report or information the head of a state organ, located on the corresponding territory, on issues of their activities. The decision was adopted if supported by more than half of deputies.

Fourthly, one of the most important innovation of the bill is set that the proposals of party groups on issues introduced in representative bodies, are subject to mandatory review. If we consider the so-called different weight representation of political parties in representative bodies of local authorities, it is the most important guarantee of strengthening the position of political parties having less number of members in the corresponding Kengash of people's deputies.

In April 2014, new amendments have been made and additions to the Constitution of the Republic of Uzbekistan [16], extending the role of the Legislative chamber and Senate of Oliy Majlis in the system of public authorities, strengthening their functions of control over the activities of the Cabinet of Ministers and Executive bodies, increasing the responsibility of the Cabinet of Ministers and local administration. They are a logical extension of the Concept of further deepening democratic reforms and formation of civil society, which incorporates an integrated analysis of distance traveled along the path of reforming the country and defined the targets and guidelines for the development of society and the state.

In particular, Article 78 of the Constitution is supplemented by a provision aimed at constitutional recognition of the powers of the Legislative chamber and Senate of Oliy Majlis of the Republic of 
Uzbekistan on the implementation of parliamentary control. The control of the legislature over the activities of Executive bodies increases the responsibility for the ongoing action for the realization of laws and decisions of the Parliament and, thus, leads to an improvement in the quality of their work. The proper discharge of the Executive power of the laws leads to the consolidation of democracy, since the implementation is based on the will of national solutions in accordance with this will deepen the awareness of the people of its role as the sole source of authority and increases his desire to influence public policy.

In addition, constitutional recognition of the powers to exercise parliamentary control will allow political parties represented in Parliament, improve the effectiveness of control over the entire system of Executive power - from government to local authorities and to strengthen their role and practical importance in social life. Most importantly, it will give political parties a much more significant and harder to defend the interests of their constituency and their mission.

In the frameworks of the implementation of the principle "from strong state to strong civil society" and the formation of the whole system to ensure public control over activities of state authorities, it is proposed to give constitutional status as the Institute of public control, which significantly enhances the role and importance of civil institutions in solving the major problems of development of the state.

Amendments to article 93 improve the mechanism of the constitutional principle of separation of powers and their effective interaction. Thus, it is proposed that the decision on the formation and abolition of ministries, state committees and other bodies of state administration with subsequent submission of decrees on these matters for approval by chambers of Oliy Majlis will be accepted by the President only upon submission of the Cabinet of Ministers of the Republic of Uzbekistan.
Also there was included a rule that a candidate for the post of Prime-Minister under the consideration and approval of his candidacy in Parliament is a programme of government action for the near and long term. Said addition will allow political parties to make an informed decision to determine its position in relation to the course and programmes of the government or its separate directions. It is of great importance for the further development of a multiparty system, inter-party competition and factional struggle, which are essential parts of a democratic society. This will be facilitated and provided for in the bill is the government's duty to annually submit to Parliament reports on major issues of social and economic life of the country.

In addition, increasing the role of political parties and Deputy groups in local Kengashes and the representative Deputy bodies will contribute to additions to the Article 103, providing for the placing on the khokim of region, district and city responsibility to present the relevant Kengash of people's deputies reports on important and topical issues of socio-economic development of the region, district, city, on which the Kengash of people's deputies to make appropriate decisions.

Add to Article 117, towards the constitutionalization of an independent system of democratic formation of the Central electoral Commission and the main principles of its activity, provide a more complete realization of constitutional rights of citizens to elect and be elected to bodies of state power, and reinforce the guarantees of the rights to freedom of expression.

Legal regulation of parties in Uzbekistan is the result of gradual evolutionary development of statelegal and political system of Uzbekistan; it is the steps along the path of advancement from a strong state to a strong civil society, in the development of real multi-party system, enhancing the activity of political parties, the succession to promote the goal.

\section{References:}

1. (2014) Konstituciya Respubliki Uzbekistan. T.: «Uzbekiston», 2014. - 40 p.

2. (1997) Zakon Respubliki Uzbekistan ot 26.12.1996 goda № 337-I «O politicheskih partiyah» // Vedomosti Olij Mazhlisa Respubliki Uzbekistan. - 1997. — N 2. — pp. 36.

3. (1994) Zakon Respubliki Uzbekistan ot 28.12.1993 goda № 990-XII «O vyborah v Olij Mazhlis Respubliki Uzbekistan»// Vedomosti
Verhovnogo Soveta Respubliki Uzbekistan. 1994. — № 1. - pp. 6.

4. (1994) Zakon Respubliki Uzbekistan ot 05.05.1994 goda № 1051-XII «O garantiyah izbiratel'nyh prav grazhdan» // Vedomosti Verhovnogo Soveta Respubliki Uzbekistan. 1994. — № 5. — pp. 127.

5. (1994) Zakon Respubliki Uzbekistan ot 5 maya 1994 goda № 1050-XII «O vyborah v oblastnye, rajonnye $\mathrm{i}$ gorodskie Sovety 


\begin{tabular}{|c|c|c|c|c|c|c|}
\hline Impact Factor: & $\begin{array}{l}\text { ISRA (India) } \\
\text { ISI (Dubai, UAE } \\
\text { GIF (Australia) } \\
\text { JIF }\end{array}$ & $\begin{array}{r}=1.344 \\
=\mathbf{0 . 8 2 9} \\
=0.564 \\
=1.500\end{array}$ & $\begin{array}{l}\text { SIS (USA) } \\
\text { PИHЦ (Russia) } \\
\text { ESJI (KZ) } \\
\text { SJIF (Morocco) }\end{array}$ & $\begin{array}{l}=0.912 \\
=0.179 \\
=1.042 \\
=\mathbf{2 . 0 3 1}\end{array}$ & $\begin{array}{l}\text { ICV (Poland) } \\
\text { PIF (India) }\end{array}$ & $\begin{array}{l}=6.630 \\
=1.940\end{array}$ \\
\hline
\end{tabular}

narodnyh deputatov» // Vedomosti Verhovnogo Soveta Respubliki Uzbekistan. — 1994. — № 5. - pp. 125.

6. (2007) It should be noted that the Institute of nomination of candidates for deputies of local representative bodies of state authority acted in the general elections of 1994 and 1999. Moreover, such a mechanism was important and necessary during the transitional period in the formation of political parties, and virtually ensured the representation of regions in the country's unicameral Parliament - the Oliy Majlis. Sm.: Politicheskie partii. - T.: Akademiya, 2007. — pp. 12.

7. (2011) «Osnovnye tendencii i pokazateli ehkonomicheskogo i social'nogo razvitiya Respubliki Uzbekistan za gody nezavisimosti (1990-2010 gg.) i prognoz na 2011-2015 gg.» // T. — «Uzbekiston», 2011. — pp. 64.

8. (2004) Zakon Respubliki Uzbekistan ot 30.04.2004 goda № 617-II «O finansirovanii politicheskih partij» // Vedomosti Olij Mazhlisa Respubliki Uzbekistan. - 2004. — № 5. - pp. 86.

9. (2007) Zakon Respubliki Uzbekistan ot 11.04.2007 goda № ZRU-88 «Ob usilenii roli politicheskih partij $\mathrm{v}$ obnovlenii i dal'nejshej demokratizacii gosudarstvennogo upravleniya $\mathrm{i}$ modernizacii strany» // Vedomosti Olij Mazhlisa Respubliki Uzbekistan. — 2007. № 4. 一 pp. 161 .

10. (2008) Zakon Respubliki Uzbekistan ot 25.12.2008 goda № ZRU-194 «O vnesenii izmenenij i dopolnenij $\mathrm{V}$ nekotorye zakonodatel'nye akty Respubliki Uzbekistan v svyazi s sovershenstvovaniem zakonodatel'stva o vyborah» // Vedomosti palat Olij Mazhlisa Respubliki Uzbekistan. — 2008. — № 12. pp. 637.
11. Karimov IA (2013) Posledovatel'noe prodolzhenie kursa na modernizaciyu strany reshayushchij faktor nashego razvitiya // Doklad Prezidenta Respubliki Uzbekistan I.A.Karimova na torzhestvennom sobranii, posvyashchyonnom 21-j godovshchine Konstitucii Respubliki Uzbekistan, 6 dekabrya 2013 goda. - Gazeta «Narodnoe slovo» ot 7 dekabrya 2013 goda.

12. (2011) Zakon Respubliki Uzbekistan ot 18 aprelya 2011 goda № ZRU-284 «O vnesenii izmenenij i dopolnenij $\mathrm{v}$ otdel'nye stat'i Konstitucii Respubliki Uzbekistan (stat'i 78, 80, 93, 96 i 98)» // Vedomosti Olij Mazhlisa Respubliki Uzbekistan. — 2011. — № 4. - pp. 102.

13. (2013) Zakon Respubliki Uzbekistan ot 18.04.2013 goda № ZRU-349 «O vnesenii izmenenij i dopolnenij v Zakon Respubliki Uzbekistan «O Reglamente Zakonodatel'noj palaty Olij Mazhlisa Respubliki Uzbekistan» // Vedomosti palat Olij Mazhlisa Respubliki Uzbekistan. - 2013. - № 4. - pp. 95.

14. (2014) Zakon Respubliki Uzbekistan ot 20.01.2014 goda № ZRU-365 «O vnesenii izmenenij i dopolnenij $\mathrm{V}$ nekotorye zakonodatel'nye akty Respubliki Uzbekistan» // Vedomosti palat Olij Mazhlisa Respubliki Uzbekistan. - 2014. — № 1. - pp. 2.

15. (2014) Zakon Respubliki Uzbekistan ot 16 aprelya 2014 goda № ZRU-366 «O vnesenii izmenenij i dopolnenij $\mathrm{v}$ otdel'nye stat'i Konstitucii Respubliki Uzbekistan (stat'i 32, 78, 93, 98, 103 i 117)»// Vedomosti palat Olij Mazhlisa Respubliki Uzbekistan. — 2014. № 4. - pp. 85 . 